\title{
HUBUNGAN PENDEKATAN LATIHAN MASSED PRACTICE DAN DISTRIBUTED PRACTICE TERHADAP KETEPATAN PUKULAN LOB PEMAIN BULUTANGKIS
}

\author{
Arie Asnaldi \\ Jurusan Pendidikan Olahraga Prodi. Pendidikan Jasmani Kesehatan dan Rekreasi Fakultas Ilmu \\ Keolahragaan. Jalan Prof. Dr. Hamka Air Tawar Barat, Padang 25132, Indonesia \\ Universitas Negeri Padang \\ E-Mail: asnaldi@fik.unp.ac.id
}

\begin{abstract}
Abstrak
Metode penelitian ini adalah eksperimen semu (quasi esperimental). Populasi penelitian ini berjumlah 47 orang, sedangkan sampel ditetapkan secara purposive sampling, yaitu: 26 orang pemain putra. Tes yang digunakan adalah tes ketepatan pukulan lob. Sedangkan analisis data yang digunakan adalah uji-t. Hasil penelitian menunjukan bahwa: 1) Pendekatan latihan Massed Practice memberikan pengaruh terhadap ketepatan pukulan $l o b$, hasil yang diperoleh $t_{\text {hitung }}>t_{\text {tabel }}=26,98>1,782$. 2) Pendekatan latihan Distributed Practice memberikan pengaruh terhadap ketepatan pukulan lob, hasil yang diperoleh $\mathrm{t}_{\text {hitung }}>\mathrm{t}_{\text {tabel }}=8,40>1,782.3$ ) Pendekatan latihan Massed Practice lebih berpengaruh dibandingkan dengan Pendekatan latihan Distributed Practice untuk meningkatkan ketepatan pukulan $l o b$, dimana hasil yang diperoleh $\mathrm{t}_{\text {hitung }}>\mathrm{t}_{\text {tabel }}=(13,66)<(1,796)$.
\end{abstract}

Kata Kunci: Pendekatan latihan, Massed Practice, Distributed Practice, pukulan lob

\section{PENDAHULUAN}

Olahraga adalah segala kegiatan yang sistematis untuk mendorong, membina, serta mengembangkan potensi jasmani, rohani, dan sosial ( Sistem keolahragaan nasional, 2005:4). Melihat pengertian olahraga diatas, jelas bahwa kegiatan olahraga yang ingin dikembangkan harus dilakukan secara sistematis, terukur, dan terarah. Sehingga dapat mendorong siswa atau atlet untuk melakukan aktifitas olahraga yang dapat membina karakter yang lebih baik dan mampu mengembangkan potensi jasmani dan rohani serta berjiwa sosial.

Seiring berjalannya waktu perkembangan ilmu pengetahuan serta teknologi dewasa ini yang berlangsung dengan cepat, banyak menyebabkan pergeseran nilainilai kehidupan, baik itu nilai sosial, budaya,ekonomi, politik bahkan tanpa terkecuali nilai-nilai olahraga itu sendiri. Olahraga yang dahulunya hanya bertujuan sebagai usaha peningkatan kualitas jasmani, telah berkembang menjadi multi tujuan, baik untuk kepentingan prestasi olahraga itu sendiri, ekonomi maupun politik. Bahkan dewasa ini olahraga telah menjadi suatu industri yang jika dikemas sedemikian rupa mampu menjadi suatu komoditi yang mempunyai nilai jual yang cukup tinggi Salah satu langkah maju yang dibuat bangsa Indonesia adalah dengan dilahirkannya Undang-Undang no 3 tahun 2005 tentang Sistem Keolahragaan Nasional. Tujuan pemerintah dalam bidang olahraga terdapat dalam bab 2 pasal 4 yang berbunyi :

"Keolahragaan nasional bertujuan memelihara dan meningkatkan kesehatan dan kebugaran, prestasi, kualitas manusia, menanamkan nilai moral dan akhlak mulia, sportifitas, disiplin, mempererat dan membina persatuan dan kesatuan bangsa, memperkokoh ketahanan nasional, serta meningkatkan harkat, martabat dan kehormatan bangsa".

Berdasarkan ketentuan di atas, dijelaskan bahwa salah satu bidang pembangunan yang ingin dicapai oleh bangsa Indonesia adalah munculnya prestasi-prestasi nasional diberbagai cabang olahraga.Seperti cabang bulutangkis Indonesia sudah banyak mengukir prestasi di cabang ini, salah satu contoh prestasi internasional yaitu tradisi mendali emas pada Olimpiade dari tahun 1992 (Alan Budikusuma dan Susi Susanti),tahun 1996 (Riky Subagja/Rexy Mainaky), tahun 2000 (Candra Wijaya/Toni Gunawan), tahun 
2004 (Taufik Hidayat), tahun 2008 (Markis Kido/Hendra Setiawan).

Bulutangkis merupakan salah satu olahraga yang populer di Indonesia, dari dahulu sampai sekarang. Hal ini dapat kita lihat dengan banyaknya prestasi yang pernah diraih oleh pemain bulutangkis kita, sehingga tidak jarang bulutangkis disebut primadonanya Indonesia yang sering membawa harum nama bangsa di tingkat Internasional.

Sesungguhnya perkembangan bulutangkis di Indonesia, tidak bisa dipisahkan dari perjuangan bangsa Indonesia secara keseluruhan baik masa lampau maupun masa sekarang ini. Hal ini tertuang dalam mukadimah anggaran dasar dan anggaran rumah tangga PBSI yang dibentuk pada tanggal 5 Mei 1951 di kota Bandung yang berbunyi "pembangunan olahraga bulutangkis adalah bagian dari pembangunan bangsa Indonesia dalam rangka mewujudkan cita-cita perjuangan bangsa" (PBSI dalam Zarwan 2011)

Namun dalam beberapa tahun terakhir ini, prestasi atlet bulutangkis Indonesia mengalami penurunan. Pada pertandingan terakhir, seperti: Kejuaraan Bulutangkis Cina Open, Indonesian Open, India Open, Malaysia Open, Japan open, Korea open, Denmark open, maupun pada olimpiade terakhir dimana Indonesia tanpa gelar satupun yang diraihnya. Penurunan prestasi bulutangkis Indonesia menjadi keprihatinan bersama bagi pemerintah, pengurus, pelatih serta masyarakat.

Untuk itu, perlu mencari solusi dari penurunan prestasi yang memprihatinkan ini yang tentu saja akan terkait erat dengan pola pembinaan bulutangkis secara nasional yang terkoordinir dan terkontrol termasuk ujung tombak pembinaan prestasi itu sendiri yaitu klub-klub Bulutangkis yang sudah cukup banyak berkembang di Indonesia. Salah satu diantara klub-klub tersebut adalah PB Andalas Jaya yang berada di pusat kota Padang

Karakteristik permainan bulutangkis dimainkan oleh dua orang dan empat orang, dengan masing-masing terdiri dari pemain tunggal putra-putri, pasangan ganda putra-putri dan pasangan ganda campuran. Permainan bulutangkis dimulai dengan penyajian bola atau servis dari salah seorang pemain kepada lawannya secara diagonal atau jalannya bola menyilang. Jika servis ini diterima oleh penerima servis maka terjadilah permainan (rally) yakni saling memukul shuttlecocks melewati atas net hingga terjadi bola tidak dalam permainan (mati).

Bila dimainkan oleh pemain yang ahli, permainan ini dianggap sebagai permainan olahraga lapangan yang paling cepat. Namun permainan pada partai tunggal dapat dikontrol untuk memenuhi kebutuhan individual pada aktivitas fisik mereka.

Ketika melakukan teknik, unsur-unsur fisik seperti kelincahan, kekuatan, dan daya tahan sangat mendukung. Selain itu pemain harus memiliki mental yang bagus. Jika semua dikolaborasikan dengan baik, seorang pemain akan mampu menjalankan permainandengan baik dalam usaha untuk memenangkan pertandingan.

Secara ideal pemain bulutangkis haruslah memiliki teknik dasar yang baik diiringi kondisi fisik dan mental yang baik juga, seperti Lin Dan ia memiliki postur yang ideal sebagai seorang atlet bulutangkis, disamping itu ia memiliki smash yang kencang, netting yang tipis, akurasi ketepatan lob yang bagus, jarang melakukan kesalahan dalam servis, dan memiliki mental bertanding yang bagus.

Karena dengan modal itulah Lin Dan memilki prestasi yang luar biasa yaitu 2 kali juara olimpiade dan 5 kali juara dunia. Pembinaan dan peningkatan prestasi olahraga yang direncanakan dengan matang dan terprogram akan mempengaruhi prestasi bulutangkis seperti yang diharapakan. Namun, prestasi tidak semudah membalikan telapak tangan. Oleh sebab itu, perlu mempertimbangkan faktor-faktor yang dapat mempengaruhi. Syafruddin (1996:22) menyatakan bahwa:

Ada dua faktor yang mempengaruhi dalam meraih suatu prestasi, faktor tersebut adalah faktor internal dan faktor eksternal. Faktor internal antara lain: fisik, teknik, taktik, dan mental (psikis) atlet, dan faktor eksternal adalah yang timbul dari luar dari diri atlet seperti: pelatih, sarana dan prasarana, guru olahraga, keluarga, metode latihan, organisasi, iklim, cuaca, makanan yang bergizi dan lain sebagainya.

Kemampuan teknik, taktik, dan mental atlet yang baik akan menjadi sia-sia jika tidak 
didukung oleh kemampuan fisiknya, permainan tidak akan dapat berlangsung lama dalam pertandingan, karena akan mengalami kelelahan sehingga akan mengganggu kemampuan teknik.

Jika fisik dan teknik terganggu, maka taktik apapun yang diterapkan pelatih akan siasia dan mental pantang menyerah pun akan menjadi percuma, sehingga penampilan dan prestasi menjadi kurang optimal. Hal ini berarti bahwa keempat aspek tersebut merupakan satu kesatuan yang saling menentukan dalam mencapai prestasi secara maksimal.

Provinsi Sumbar merupakan salah satu daerah yang tidak pernah absen mengirim atletnya pada kejuaraan tingkat wilayah maupun nasional. Sebagai buktinya dimana pada tahun 2012 atlet bulutangkis Provinsi Sumbar lolos pekan Olahraga Nasional di Riau.

Kota Padang adalah salah satu kota di Provinsi Sumbar yang mempunyai peran aktif dalam kemajuan prestasi bulutangkis. Di Kota Padang sendiri telah banyak berdiri PB (Persatuan Bulutangkis) salah satu diantaranya adalah PB Andalas Jaya yang berada di pusat kota Padang. PB Andalas jaya Kota Padangberlatih dilapangan indor dengan jadwal latihan lima kali dalam satu minggu.

Namun demikian, dalam hal prestasi altet bulutangkis PB Andalas Jaya Padang belum dapat menunjukkan prestasi yang terbaik, artinya masih minim prestasi, sebagai bukti diantaranya pada kejuaraan daerah tahun 2013 hanya mendapat 1 mendali perak dan 2 perunggu (Pengurus PB Andalas Jaya Kota Padang). Atlet yang tergabung dalam klub PB Andalas Jaya Padang memiliki umur berkisar 13-16 tahun, yang rata-rata atletnya sudah berlatih di atas 1 tahun.

Berdasarkan pengamatan yang selama ini peneliti lakukan,pada saat pemain PB Andalas jaya Kota Padang melakukan pertandingan dan saat latihan terlihat kemampuan teknik dasar yang masih belum dikuasai dengan baikseperti teknik pukulan smash, drive,dropshot, lob, servis, net play, olah kakidan pola-pola pukulan sehinggapemain tidak bisa menampilkan permainan terbaiknya.

Yang jelas menonjol adalah padapukulan lob,mengingat pukulan $l o b$ merupakan salah satu teknik pukulan yang sangat penting dalam permainan
bulutangkis.Lob merupakan pukulan melambung shuttle cock yang diarahkan tinggi kebelakang wilayah lawan. Pukulan lob ini bertujuan untuk mendesak posisi lawan, agar posisi lawan yang stabil berubah menjadi kacau sehingga serangan selanjutnya bisa menerobos pertahanan lawan, selain itu pukulan lob juga dapat sebagai pukulan untuk bertahan atau lazim disebut defensive lob.

Pukulan lob tidak selalu merupakan pukulan bertahan, tetapi juga dapat digunakan untuk menyerang. Perbedaanya terletak pada trayek lambungan bola yang lebih rendah dan jalanya bola yang lebih cepat atau lazim disebut lob menyerang (Attack lob), pukulan ini menjadi senjata yang ampuh merusak atau menipu lawan.

Kemampuan $l o b$ pemain $\mathrm{PB}$ Andalas Jaya Kota Padang masih kurang maksimal, banyak diantaranya pukulan yang dilakukan sangat lemah atau terlalu keras atau tidak sempurna sehingga menguntungkan bagi lawan, dengan tujuan menjatuhkan shuttlecock di lapangan depan lawan sering kali shuttlecock menyangkut di net atau tidak melewati net dan sering juga laju shuttlecock terlalu tinggi di atas net sehingga menguntungkan bagi lawan.

Di dalam bulutangkis, setiap pukulan memerlukan serangkaian koordinasi gerak tubuh yang kompleks begitu juga dengan pukulan lob. Faktor-faktor kondisi fisik penunjang pukulan lob juga harus diperhatikan diantaranya daya ledak otot lengan, kelentukan dan koordinasi dengan tujuan pukulan ini dapat dilakukan dengan sempurna dan dapat meraih prestasi yang lebih baik.

Terdapat banyak faktor yang mempengaruhi untuk mendapatkan kemampuanlobyang baik diantaranya seperti teknik pukulan, kekuatan genggaman tangan, strategi permainan, koordinasi, program latihan, tinggi badan, kecepatan, kekuatan fisik, daya ledak dan kelentukan, metode latihan,seperti contoh: Pendekatan latihan analisis-sintesis, global, elementer, massed practice dan distributed practice.

Pendekatan latihan diatas, tentunya sangat tergantung dari karakteristik atletnya, karena tidak semua pendekatan latihan yang diterapkan memiliki dampak yang sama untuk atlet, artinya antara atlet satu dengan yang lain nya memiliki karakter yang berbeda-beda. Ini merupakan hal yang menarik untuk diteliti 
khususnya keberhasilan dalam menempatkan setiap pukulan lob dalam permainan bulutangkis.

\section{METODE}

Jenis penelitian ini adalah eksperimen semu (quasieksperiment). Tujuannya adalah untuk menemukan ada tidaknya pengaruh perlakuan antara sebab dengan akibat antara variable-variabel yang dikontrol (Suharto, dkk, 2004 : 38). Penelitian ini dimaksudkan untuk melihat pengaruh hasil latihan terhadap penyampaian materi latihan dengan menggunakan pendekatan dengan metode latihan massed practice dan distributed practice terhadap ketepatan pukulan lob pemain bulutangkis.

Rancangan penelitian ini terdiri dari dua kelompok sampel dengan proses penelitian yang dilaksanakan dalam tiga tahapan yaitu: melaksanakan tes awal (pretest) yang bertujuan memperoleh data awal tentang ketepatanlobpemain bulutangkis PB Andalas Jaya Padang.

Kemudian sampel dibagi menjadi dua kelompok dengan cara ordinlly matched pairing agar kedua sampel bisa homogen. Selanjutnya dilakukan penentuan kelompok mana yang akan diberikan perlakuan (treatment) pendekatan metode latihan massed practice dandistributed practice. Tahap selanjutnya dapat dilakukan tes akhir (post test). Lebih jelasnya dapat dilihat pada tabel berikut ini:

\begin{tabular}{|c|c|c|c|}
\hline \multirow{2}{*}{$\begin{array}{c}\text { Pretest } \\
\text { (tes awal) }\end{array}$} & $\begin{array}{c}\text { Teknik } \\
\text { pembagian } \\
\text { kelompok }\end{array}$ & $\begin{array}{c}\text { Perlakuan } \\
\text { (Treatment) }\end{array}$ & $\begin{array}{c}\text { Post test } \\
\text { (tes } \\
\text { akhir) }\end{array}$ \\
\hline \multirow{2}{*}{$\mathrm{T} 1$} & $\begin{array}{c}\text { Ordinary } \\
\text { matched pairing }\end{array}$ & $\begin{array}{c}\text { Massed practice } \\
\text { practice }\end{array}$ & \multirow{2}{*}{$\mathrm{T} 2$} \\
\hline
\end{tabular}

\section{HASIL DAN PEMBAHASAN}

1. Hasil Pre test dan Post test ketepatan lob pemain bulutangkis PB Andalas Jaya Padang pada kelompok Massed Practice.

Berdasarkan analisis data test awal (pre test) kelompok Massed Practice dengan jumlah sampel 13 orang diperoleh skor tertinggi 14 , skor terendah 7 , rata-rata (mean) 10,15 , dan standard deviasi (SD) 1,99. Selanjutnya dari analisis test akhir (post test) setelah 16 kali perlakuan didapat skor tertinggi 19 skor terendah 13 rata-rata 15,31 , dan standard deviasi (SD) 1,80 .

\section{Hasil Pre test dan Post test ketepatan lob pemain bulutangkis PB Andalas Jaya Padang pada kelompok Distributed Practice.}

Berdasarkan analisis data test awal (pre test) kelompok Distributed Practice dengan jumlah sampel 13 orang diperoleh skor tertinggi 14 , skor terendah 7 , rata-rata (mean) 10,31, dan standard deviasi (SD) 1,93. Selanjutnya dari analisis test akhir (post test) setelah 16 kali perlakuan didapat skor tertinggi 17 skor terendah 8 rata-rata 11,85 , dan standard deviasi (SD) 2,38.

\section{Pembahasan}

Melihat masalah pada pemain bulutangkis PB Andalas Jaya Padang yaitu kurangnya ketepatan pukulan lob pada pemain, maka perlu dilakukan latihan untuk meningkatkan ketepatan pukulan $l o b$ tersebut. Dalam hal ini latihan yang diberikan adalah dengan MassedPractice dan Distibuted Practice. Dari penggunaan kedua kelompok ini akan dilihat apakah ada pengaruh terhadap ketepatan pukulan $l o b$.

Sebelum eksperimen diberikan kepada sampel, terlebih dahulu dilakukan tes awal (pre test) guna memperoleh data awal. Setelah data awal didapatkan lalu kelompok telah dibagi berdasarkan machingsetelah itu diberikan latihan sebanyak16 kali pertemuan, banyaknya hari latihan dalam seminggu adalah tiga kali yaitu pada hari senin, rabu, jumat, minggu, lama latihan dalam satu kali pertemuan adalah 90 menit, senin, rabu dan jum'at pukul 16.0017.30 dan hari minggu pukul 08.00-09.30.

Untuk mendapatkan data yang lebih akurat maka perlu kiranya dilakukan pengkajian tentang metodologi dan kajian teori yang mendukung terhadap suatu penelitian. Dengan menggunakan pendekatan ilmiah dan dibuat berdasarkan teori tertentu serta dilakukan dalam suatu metode yang sistematis dengan langkah-langkah maupun prosedur yang benar, maka diharapkan hasil penelitian ini dapat diterima kebenarannya.

\section{Pendekatan latihan massed practice memberikan pengaruh terhadap ketepatan pukulan lobpemain bulutangkis PB Andalas jaya Padang. \\ Pada hasil post test kelompok Massed} Practice terhadap ketepatan pukulan lob pemain bulutangkis PB Andalas Jaya Padang 
dari tes awal dan tes akhir dari skor rata-rata 10,15 pada pre test menjadi 15,31 pada post test. Hal ini berarti hipotesis penelitian yang mengatakan Massed Practie berpengaruh terhadap ketepatan pukulanlob dapat diterima kebenarannya. Terjadi peningkatan ini kemungkinan disebabkan oleh adaptasi teknik dari Massed Practice ini pemain dituntut sangat aktif untuk melakukan gerakan yang di instruksikan pelatih.

Massed practice adalah bentuk pembelajaran motorik, dimana bentuk gerakan yang dipelajari akan dilakukan tanpa berhenti. Massed Practice adalah kegiatan dengan alokasi istirahat diantara percobaan relative pendek atau tanpa istirahat sama sekali apabila dibandingkan dengan panjang atau lamanya percobaan (latihan).

Proses belajar teknik tidak boleh terhentihenti (terputus-putus) dalam waktu yang lama antara setiap satuan latihan, karena dapat mengurangi efekitifitas latihan. Dengan demikian latihan tekhnik yang baik itu adalah latihan yang dilakukan secara terus menerus tanpa terputus-putus sehingga akan menciptakan otomatisasi pada setiap gerakan yang dilakukan.

Massed practice selalu diartikan sebagai latihan yang dilakukan beberapa menit sampai beberapa jam atau sejumlah bentuk latihan yang dilakukan puluhan bahkan ratusan kali percobaan untuk setiap unit latihannya.

Bila dilihat dari kegiatan yang dilakukan, maka massed practice memiliki ciri yang sama dengan kekuatan yang bersumber energi aerobik, karena untuk setiap kegiatan yang dilakukan tidak diselingi dengan masa waktu istirahat. Ini berati bahwa untuk jumlah satu tugas dilaksanakan sekaligus, kegiatan ini memiliki konsekuensi lain yaitu terkurasnya glikogen alat sebagai cadangan energi yang menimbulkan rasa lelah.

Unjuk kerja dibawah kondisi Massed Practice lebih jelek dibandingkan dengan distributed practice. Selanjutnya ditambahkan bahwa beberapa sesi unjuk kerja menjadi rusak dibawah Massed practice, ini disebabkan karena kelelahan yang dialami pada saat latihan yang dilakukan.

Namun dilihat dari unjuk kerja yang diberikan pada pemain yang terlatih dan mempunyai motivasi yang tinggi, kelompok massed practice lebih baik dibandingkan distributed practice. Pada kelompok massed practice lebih baik ketika tingkat keterampilan pemain tinggi dan ketika kinerja puncak pada belajar keterampilan lebik baik digunakan. Massed practice lebih disukai bila keterampilan sangat bermakna, ketika motivasi tinggi, dan bila ada dukungan dari tugas gerak yang baru.

Sejauh gerak tugas yang lama bias diimbangi tanpa mengurangi jumlah pembelajaraan, efisinsi dari sesi latihan dapat ditingkatkan. MassedPractice lebih tepat digunakan diawal sesi latihan dan bagi pemain yang terlatih. Dimana pada massedpractice ini akan tercipta satu keterbiasaan terhadap tugas gerak yang dilakukan karena kegiatanya dilakukan secara terus menerus dang berulangulang.

\section{Pendekatan latihan distributed practicememberikan pengaruh terhadap ketepatanlobpemain bulutangkisPB Andalas jaya Padang.}

Pada hasil post test kelompok Distributed Practice terhadap ketepatan pukulan lob pemain bulutangkis PB Andalas Jaya Padang dari tes awal dan tes akhir dari skor rata-rata 10,31 pada pre test menjadi 11,85 pada post test. Hal ini berarti hipotesis penelitian yang mengatakan Distributed Practie berpengaruh terhadap ketepatan pukulanlob dapat diterima kebenarannya. Terjadi peningkatan ini kemungkinan disebabkan oleh adaptasi teknik dari Distributed Practice ini pemain diberikan waktu jeda/istirahat setelah melakukan sebuah gerakan.

Distributed practice adalah Praktek yang diselingi dengan istirahat. Distributed Practice adalah memperaktekan gerakan yang dipelajari dengan mengatur secara selang-seling antara waktu praktek dan waktu istirahat. DistributedPractice adalah kegiatan latihan dengan alokasi jumlah istirahat yang relatif lama setiap percobaan dibandingkan dengan lamanya percobaan yang dilakukan.

Berdasarkan pendapat diatas dapat diartikan bahwa distributed practiceadalah suatu kegiatan atau praktek latihan yang dilakukan dengan alokasi istirahat diantara percobaan diselingi dengan istirahat dalam suatu rangkaian gerakan atau percobaan (Latihan).

Sehingga pada distributed Practice ada pengaturan giliran melakukan gerakan berapa kali, kemudian istirahat dan setelah itu 
melkukan gerakan kembali. Bentuk unjuk rasa ini sama dengan bentu latihan interval training guna untuk meningkatkan daya tahan anaerobik.

Pengaturan waktu latihan erat hubungannya dengan perhitungan beberapa kali sebaiknya setiap pemain mengulang-ulang melakukan gerakan keterampilan yang dipelajari agar hasil belajarnya yang berupa penguasaan gerakan bisa memadai. Mengenai banyaknynya ulangan, secara umum dapat dikatakan bahwa semakin banyak mengulangngulang maka gerakan semakin bisa dikuasai. Misalnya pada saat pemain mempelajari pukulan lob bulutangkis, semakin banyak mengulangi maka gerakanya nya semakin dikuasai dan ketepatan lob bulutangkis nya pun meningkat.

Beberapa hasil penelitian tentang pembelajaran motorik yang menggunakan bentuk tersebut, menyebutkan tidak semua kemampuan motorik sesuai dengan cara tersebut, distributed practice kelihatanya lebih sesuai dengan gerakan yang bersifat fine motorik.

Subjek yang berlatih dengan memamfaatkan priode istirahat satu menit atau satu hari dalam masa percobaan, menghasilkan unjuk kerja yang lebih baik setelah 20 kali mencoba dibandingkan dengan latihan secara terus menerus. Sedangkan apabila dikaitkan dengan intelegensi motorik (koordinasi gerak) tinggi,

Distributed practice merupakan pilihan yang paling sesuai dengan belajar motorik. Artinya apabila dikaitkan dengan system energy atau tenaga, distributed practice lebih cocok apabila energi yang dibutuhkan dari tugas gerak ini tinggi, rumit, tugas dilakukan dalam waktu yang relative lama, tugas ini memberikan arti khusus dan motivasi pembelajar rendah.

\section{Pendekatan latihan massed practicelebih berpengaruh dari pada distributed practice terhadap ketepatan pukulanlobpemain bulutangkis PB Andalas JayaPadang.}

Pada hasil post test kelompok Massed Practice dan kelompokDistributedPractice terhadap ketepatan pukulan lob pemain bulutangkis PB Andalas Jaya Padang dengan skor rata-rata 15,31 pada kelompokMassed Practice sedangkan pada kelompok
Distributed practicedengan nilai rata-rata 11,85 dan dengan hasil penghitungan hipotesis $t_{\text {hitung }}(13,66)>t_{\text {tabel }}(1,796)$ itu artinya hipotesis diterima. Hal ini berarti hipotesis penelitian yang mengatakan Massed Practicelebih berpengaruh dari pada Distributed Practice

Diterima dan memberikan pengaruh yang signifikan terhadap ketepatan pukulan lob pemain bulutangkis PB Andalas Jaya Padang. Hasil pengujian hipotesis menunjukan bahwa secara keseluruhan, skor kelompok Massed Practice lebih tinggi dari pada yang diberikan Distributed practice.

Kelompok Massed Practice lebih baik dari kelompok Distributedpractice. Hal ini dapat dilihat dari hasil analisis statistik dengan selisih mean Massedpractice 15,31 dan Distributed Practice 11,85, ini berarti memberikan latihan dengan menggunakan Massed Practice memberikan pengaruh yang lebih baik dibandingkan dengan DistributedPractice.

Massed practice adalah bentuk pembelajaran motorik, dimana bentuk gerakan yang dipelajari akan dilakukan tanpa berhenti. Massed Practice adalah kegiatan dengan alokasi istirahat diantara percobaan relative pendek atau tanpa istirahat sama sekali apabila dibandingkan dengan panjang atau lamanya percobaan (latihan).

Proses belajar teknik tidak boleh terhentihenti (terputus-putus) dalam waktu yang lama antara setiap satuan latihan, karena dapat mengurangi efekitifitas latihan. Dengan demikian latihan tekhnik yang baik itu adalah latihan yang dilakukan secara terus menerus tanpa terputus-putus sehingga akan menciptakan otomatisasi pada setiap gerakan yang dilakukan.

Distributed Practiceadalah suatu kegiatan atau praktek latihan yang dilakukan dengan alokasi istirahat diantara percobaan diselingi dengan istirahat dalam suatu rangkaian gerakan atau percobaan (Latihan). Sehingga pada distributed Practice ada pengaturan giliran melakukan gerakan berapa kali, kemudian istirahat dan setelah itu melkukan gerakan kembali. Bentuk unjuk rasa ini sama dengan bentu latihan interval training guna untuk meningkatkan daya tahan anaerobik.

Pengaturan waktu latihan erat hubungannya dengan perhitungan beberapa kali sebaiknya setiap pemain mengulang-ulang melakukan gerakan keterampilan yang 
dipelajari agar hasil belajarnya yang berupa penguasaan gerakan bisa memadai. Mengenai banyaknynya ulangan, secara umum dapat dikatakan bahwa semakin banyak mengulangngulang maka gerakan semakin bisa dikuasai. Misalnya pada saat pemain mempelajari pukulan lob bulutangkis, semakin banyak mengulangi maka gerakanya nya semakin dikuasai dan ketepatan lob bulutangkis nya pun meningkat.

Kedua metode di atas disusun berdasarkan kesamaan intensitas, dan durasi atau lamanya waktu latihan. Berdasarkan hasil penelitian Massed Practice lebih baik dari pada DistributedPractice. Dalam proses latihan Massed Practice merupakan bentuk latihan yang dilakukan secara terus menerus tanpa jeda/waktu istirahat.

Dalam latihan ketepatan pukulan lob pemain diberikan latihan secara terus menrus agar pemain mampu menguasai apa yang diberikan pelatih dengan cepat pula. Salah satu cara untuk meningkatkan ketepatan pukulan lob adalah dengan Massed Practice. Dengan adanya metode MassedPractice ini maka sangat dianjurkan kepada pemain untuk meningkatkan ketepatan pukulan lobnya. Agar mampu menguasai ketepatan pukulan lob secara maksimal.

\section{KESIMPULAN}

Berdasarkan analisi data dan pembahasan yang telah dipaparkan terdahulu, maka dapat dikemukakan beberapa kesimpulan sebagai berikut:

1. Pendekatan latihan Massed Practice memberikan pengaruh terhadap ketepatan pukulan $l o b$, hasil yang diperoleh $t_{\text {hitung }}>$ $\mathrm{t}_{\text {tabel }}=26,98>1,782$.

2. Pendekatan latihan Distributed Practice memberikan pengaruh terhadap ketepatan pukulan $l o b$, hasil yang diperoleh $\mathrm{t}_{\text {hitung }}>$ $\mathrm{t}_{\text {tabel }}=8,40>1,782$.

3. Pendekatan latihan Massed Practice lebih berpengaruh dibandingkan dengan Pendekatan latihan Distributed Practice untuk meningkatkan ketepatan pukulan $l o b$, dimana hasil yang diperoleh $t_{\text {hitung }}$ $>t_{\text {tabel }}=(13,66)<(1,796)$.

\section{DAFTAR RUJUKAN}

Donie. 2009. Pembinaan Bulutangkis Prestasi. Wineka Media. Padang
Khairuddin. 2001. Pedoman Permainan Bulutangkis. Padang: UNP.

Stevan R. Murray, D.A., and Brian E. Uderman. 2003. Massed Versus Distributed Practice: Which is Better?. (Online), Vol. 28, NO. 1 ( www. Cahperd journal.com. Diakses 9 maret 2014).

Syafruddin. 1996. Pengantar Ilmu Melatih. Padang: FPOK IKIP.

Syahara, Sayuti. 1999. Ketepatan Latihan Melempar Sasaran. Disertasi. Jakarta: Program Pascasarjana UNJ.

Tohar. 1992. Olahraga pilihan Bulutangkis. Jakarta :Debdikbud, Dirjen Dikti P2TK.

Undang-undang Republik Indonesia Nomor 3 Tahun 2005. 2005. Himpunan Peraturan Perundang - undangan Republik Idonesia Tentang Sistem Keolahragaan Nasional. Nuansa Aulia.

Yanuar kiram. 1992. Belajar motorik. Jakarta: Depdikbud-Dikti-P2TP.

Zarwan. 2010. Bulutangkis. Padang: Sukabina Press. 
Vol. 1, NO. 2, November 2016 